\title{
PERANCANGAN APLIKASI PENGOLAHAN DATA TABUNGAN SISWA BERBASIS DELPHI PADA SMP MUHAMMADIYAH AHMAD DAHLAN KOTA METRO
}

\author{
Solehan Budi Saputra ${ }^{(1)}$ Ika Artahalia Wulandari ${ }^{(2)}$ \\ Jurusan Ilmu Komputer, Fakultas Ilmu Komputer,Universitas Muhammadiyah Metro \\ Jl.Gatot Subroto No.100 Yosodadi Kota Metro, Telpon :(0725)42445-Fax(0725)42454 \\ e-mail : $\underline{\text { ikaarthalia@gmail.com }}$
}

\begin{abstract}
Abstrak
Secara garis besar penulis dapat mengemukakan bahwa sebagian sistem yang sedang berjalan belum cukup baik, karena sistem yang berjalan saat ini masih banyak mengalami kendala, salah satunya yaitu dalam proses pengolahan data tabungan siswa. Dalam tabungan siswa yang terjadi pada saat ini adalah masih dilakukannya proses manual yaitu dengan cara siswa memberikan buku tabungan ke petugas tabungan, setelah itu maka petugas tabungan akan mulai memproses penabungan secara manual, pertama petugas tabungan akan mencatat data setoran tabungan siswa dalam buku besar, setelah dicatat maka petugas menandatangani buku tabungan siswa untuk bukti bahwa siswa tersebut telah melakukan setoran tabungan, setelah proses selesai buku tabungan di kembalikan ke siswa. Hasil penelitian menggunakan metode berupa pengamatan, wawancara, dokumentasi dan studi pustaka. Sedangkan aplikasi yang digunakan untuk merancang pengolahan data tabungan siswa menggunakan Borland Delphi 7 dan database MySQL. Tahapan yang harus dilalui dalam merancang Perancangan Aplikasi Pengolahan Data Tabungan Siswa Berbasis Delphi Pada SMP Muhammadiyah Ahmad Dahlan Kota Metro digunakannya diagram konteks, Data Flow Diagram Level 0, Entity Relationship Diagram, dan Flowchart sebagai aliran informasi dan aliran data sistem aplikasi.
\end{abstract}

KUNCI : Pengolahan Data, Tabungan Siswa, Berbasis Delphi 7.0, Tabungan Siswa. SMP Muhammadiyah Ahamad Dahlan. Laporan Data Tabungan Siswa SMP Muhammadiyah Ahmad Dahlan.

\section{PENDAHULUAN}

SMP Muhammadiyah Ahmad Dahlan adalah sekolah yang menerapkan Pendidikan Holistic berbasis nilai islam, dengan terapan pembelajaran Full Day School, mencetak peserta didik yang tidak hanya unggul dalam bidang akademik tetapi juga bidang non Akademik, dengan terapan sistem pembelajaran peminatan, pembelajaran sesuai dengan kompetensi masing-masing siswa, dan pendekatan berbasis kompetensi anak, sekolah yang beralamat di JL. AR. Prawiranegara, Mulyojati, Metro Barat, Kota Metro ini sudah berdiri sejak tanggal 05 Maret 2015 setelah peletakan batu pertama oleh Prof. Dr. KH. Muhammad Sirajuddin Syamsuddin, MA Ketua Umum Pimpinan Pusat Muhammadiyah periode 2005-2010 dan 2010-2015. Dalam meningkatkan kualitas pelayanan dan pembelajaran tentunya SMPMu Ahmad Dahlan telah bersikap Ikhlas dan bersungguh-sungguh dalam mengembangkan Amanah 
persyarikatan dimana SMP Muhammadiyah Ahmad Dahlan sebagai basis dakwah dibidang pendidikan, Allah Jalla wa 'Alaa berfirman

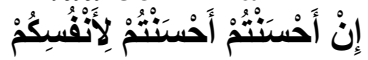

"Jika kalian berbuat baik, sesungguhnya kalian berbuat baik bagi diri kalian sendiri", (QS. Al-Isra:7).

SMP Muhammadiyah Ahmad Dahlan sejak berdirinya pada tahun 2015 telah banyak sekali menorehkan prestasi baik di bidang akademik dan non akademik, namun dalam hal pengolahan uang tabungan berupa nilai uang dan pendataanya menggunakan buku besar dan media cetak berupa buku profil sekolah yang dilampirkan list data siswa yang menabung, dan pemasukan data uang siswa yang dalam pengelolaannya tidak dioptimalkan dengan pemanfaatan media elektronik sehingga terkesan tidak transparan, menyulitkan siswa atau siswi dalam melihat perkembangan teknologi dalam bidang elektronik. Dengan berkembangnya ilmu pengetahuan dan teknologi sekarang ini sangat berpengaruh terhadap aspek kehidupan, salah satunya dalam bidang informasi yaitu dengan munculnya komputer sebagai alat bantu dalam melakukan pengolahan data dan pembuatan laporan. Komputer merupakan salah satu alat bantu bagi manusia dalam melakukan pengolahan data baik bidang pendidikan, kesehatan, instansi pemerintah maupun badan usaha lainnya. Kemajuan Ilmu Pengetahuan dan Teknologi (IPTEK) yang mengakibatkan banyak perubahan disegala bidang, salah satunya di bidang pengolahan data tabungan dalam pencatatan masih menggunakan buku besar, akibatnya data tabungan tidak berurutan, dan besaran tabungan antara buku besar dengan aplikasi excel tidak sama, akibatnya ada selisih uang yang membingungkan petugas tabungan pada SMP Muhammadiyah Ahmad Dahlan. Mau tidak mau bagian pengolahan data tabungan ini harus menangani masalah para siswa/siswi. Untuk itu harus adanya sistem kerja yang praktis dan efisien sehingga bisa mempelancar kegiatan di Kantor tersebut. Dalam hal ini dibutuhkan tenaga yang profesional dengan pengertian mampu merubah suatu sistem kerja sehinga bisa menghasilkan sistem yang aman dan efisien, mungkin untuk bisa lebih mudah dan mempelancar suatu pekerjaan yang tentunya sesuai dengna keahlian dan kemampuan yang dimilkinya. SMP Muhammadiyah Ahmad Dahlan berupaya untuk menunjang kerjanya dengan sistem informasi sehingga memberikan sistem informasi data keuangan, adanya komputer tetapi masih meggunakan cara-cara yang menual. Dengan sistem ini diperlukan banyak pegawai dan menghabiskan waktu yang lama untuk menyelesaikan suatu tugas, khususnya dibidang pengolahan data tabungan. Bertitik tolak dari masalah diatas maka SMP Muhammadiyah Ahmad Dahlan dirasa perlu meggunakan program khusus sebagai alat pengolahan data tabungan siswa agar informasi yang dibutuhkan dapat segera diperoleh dan diproses dengan efisien dan efektif. Dengan demikian hasil yang diperoleh akan sesuai dengan yang diharapkan. Dengan adanya komputer sebagai alat bantu dalam pengolahan data maka penulis merasa tertarik untuk membuat tugas akhir dengan judul "Perancangan Aplikasi Pengolahan Data Tabungan Siswa Berbasis Delphi pada SMP Muhammadiyah Ahmad Dahlan". Permasalahan yang ditemukan selama Kuliah Kerja Praktek (KKP) di SMP Muhammadiyah Ahmad Dahlan adalah belum maksimalnya pemanfaatan media elektronik sebagai pembantu sistem kerja, akibatnya stap administrasi kesulitan dalam menangani siswa atau siswi yang hendak menabung. Berdasarkan kebutuhan dan permasalahannya maka SMP Muhammadiyah Ahmad Dahlan sangat memerlukan sebuah terobosan perancangan 
sistem pengolahan data tabungan siswa, dapat membantu perkembanga sistem komputerisasi, dalam hal ini perlu ditambahkan layanan pengolah antara stap administrasi dan siswa atau siswi secara cepat, sehingga bagi siswa atau siswi dapat menabung dengan baik dan tertip tidak menimbulkan kegaduhan yang tidak diinginkan. Terobosan yang dimaksud tentunya dapat mempermudah siswa atau siswi dalam menabung melalui aplikasi tersebut, sehingga tentunya sangat bermanfaat bagi petugas administrasi khususnya petugas tabungan, seperti sabda rasullullah Shallallahu'alaihi Wasallam pernah bersabda bersabda :

للِناسِ أَنْفَهُهُمْ الناسِ خَيَرُ

"Sebaik Baik Manusia Adalah Yang Paling Bermanfaat Bagi Orang Lain", (HR.Ahmad).

Berdasarkan latar belakang dan permasalahan tersebut diatas maka SMP Muhammadiyah Ahmad Dahlan sangat membutuhkan sebuah terobosan aplikasi yang menjawab permasalahan-permasalahan tersebut yaitu "PERANCANGAN APLIKASI PENGOLAHAN DATA TABUNGAN SISWA BERBASIS DELPHI PADA SMP MUHAMMADIYAH AHMAD DAHLAN KOTA METRO”.

\section{KAJIAN PUSTAKA DAN LANDASAN TEORI}

\subsection{Definisi Perancangan}

Menurut Adi (2001:260) mengatakan "Perancangan adalah proses, cara, pembuatan merancang".

Menurut Ladjamudin (2005:39) menjelaskan bahwa :

"Perancangan adalah tahap perancangan (design) memiliki tujuan untuk mendesain sistem baru yag dapat menyelesaikan masalah-masalah yang dihadapi perusahanaan yang diperoleh dari pemilihan alternatif sistem yang baik".

Menurut Hartono (2001: 209) tujuan utama perancangan sistem adalah :

Untuk memenuhi kebutuhan para pemakai sistem.

Untuk memberikan gambaran yang jelas dan rancangan bangun yang lengkap kepada progremer.

Kedua tujuan ini lebih fokus pada perancangan atau desain sistem yang terperinci yaitu pembuatan rancangan bangunan yang jelas dan lengkap yang nantinya digunakan untuk pembuatan program komputer.

\subsection{Definisi Aplikasi}

Istilah aplikasi berasal dari bahasa inggris "application" yanng berarti penerapan dan penggunaan. Sedangkan secara istilah, pengertian aplikasi adalah suatu program yang siap untuk digunakan yang dibuat untuk melaksanakan suatu fungsi bagi penggunana jasa aplikasi lain yang dapat digunakan oleh suatu sasaran yang dituju. Ada beberapa pendapat tentang definisi yang di kemukakan oleh para ahli antara lain :

Menurut Indrajani (2014:4) “aplikasi adalah program yang menentukan aktivitas pemrosesan informasi yang di butuhkan untuk penyelesaian tugas-tugas khusus dari pemakaian komputer".

Menurut kamus komputer eksekutif, aplikasi mempunyai arti yaitu pemecahan maslah yang menggunakan salah satu tehnik pemrosesan data aplikasi yang biasanya bepacu pada sebuah komputansi yang diinginkan atau diharapkan mampu memproses data yang di harapkan.

Menurut Budiharto yang dikutip Suryadi (2016:9) "Aplikasi merupakan program yang dapat berjalan di komputer tersendiri (stand alone computer), dari mulai program yang simpel sampai dengan program besar atau rumit”. 
Menurut Simarmata yang dikutip Suryadi (2016:10) "Aplikasi adalah suatu program yang dirancang untuk membantu performa dari tugas tertentu, seperti pengolahan kata akuntansi, atau manajemen inventori".

\subsection{Definisi Data}

Data adalah catatan atas kumpulan fakta. Data merupakan bentuk jamak dari datum, berdasar dari bahasa latin yang berarti "suatu yang diberikan". Dalam penggunaan sehari-hari data berarti suatu pernyataan yang di terima secara apa adanya. Ada beberapa pendapat tentang definisi data menurut para ahli antara lain :

Menurut indrajani (2014:3) "Data adalah fakta atau obsevasi mentah yang biasanya mengenai fenomena fisik atau transaksi bisnis. Lebih khusus lagi, data adalah ukuran objektif dari antribut (karakteristik) dari entitas, seperti orang-orang, tempat, benda atau kejadian".

"Data merupakan bahan mentah untuk diolah yang hasilnya kemudian menjasdi informasi." (Janner simarmata, 2010:53)

Menurut Kadir (2003:29) menjelaskan "Secara konseptual data adalah deskripsi tentang benda, kejadian, aktivitas, dan transaksi, yang tidak mempunyai makna atau tidak berpengaruh secara langsung kepada pemakai.

Menurut Nugroho (2005:29) menjelaskan "Data adalah deskripsi tentang benda, kejadian aktivitas, dan transaksi, yang tidak mempunyai makna atau tidak berpengaruh secara langsung kepada pemakai"

Berdasarkan definisi di atas, dapat di simpulkan bahwa data adalah kumpulan dari angka, simbol, fakta-fakta dari suatu kenyataan yang apa bila diolah akan menghasilkan suatu informasi.

\subsection{Pengolahan Data}

Pengolahan data adalah bentuk pengolahan terhadap data untuk membuat data itu berguna sesuai dengan hasil yang di inginkan yang dapat digunakan. Ada beberapa pendapat tentang definisi pengolahan data menurut para ahli antara lain sebagai berikut ini :

"Pengolahan data adalah menipulasi kedalam bentuk yang lebih berguna dan lebih berarti yaitu informasi."(Janner Simarmata, 2010:53)

Menurut Ladjamudin (2013:9) menjelaskan "Pengolahan data adalah masa atau waktu yang digunakan untuk mendeskripsikan perubahan bentuk data menjadi informasi yang memiliki kegunaan".

Berikut siklus informasi pengolahan data

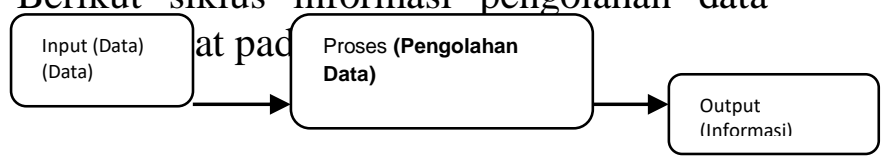

Gambar 2.1 Input, Proses dan Kerja pengolahan data.

Operasi yang dilakukan dalam pengolahan data antara lain:

Masukan (Input)

Tahap ini merupakan proses memasukan data kedalam proses komputer lewat alat input (input device)

Proses (Processing)

Tahap ini merupakan pengolahan dari data yang sudah dimasukan yang dilakukan oleh alat pemrosesan (processing device), yang dapat berupa proses menghitung, membandingkan, mengklasifikasi, mengurutkan, mengendalikan.

Keluaran (output)

Tahap ini merupakan proses yang menghasilkan output dari hasil pengolahan data kealat output (output device).

\subsection{Definisi Tabungan}

Tabungan khususnya tabungan umum merupakan inti dari sistem keuangan setiap sekolahan. Sebagai lembaga keuangan yang 
menjadi tempat bagi khas sekolah, badanbadan penyetor dari siswa, maupun perorangan dalam menyimpan danadananya, tabungan siswa dapat berperan sebagai perantara dari produsen ke konsumen dan sebagai stabilisator mekanisme sistem pembayaran bagi semua sektor perekonomian melalui kegiatan perkreditan dan berbagai jasa yang diberikan.

Definisi tabungan dapat dikelompokkan menjadi tiga :

Sebagai simpanan siswa, sekolah menerima uang serta dana-dana lain dari siswa maupun guru-guru dalam bentuk :

Simpanan atau tabungan biasa yang dapat diminta atau diambil kembali setiap saat ;

Deposito berjangka, yang merupakan tabungan atau simpanan yang penarikannya kembali hanya dapat dilakukan setelah jangka waktu yang ditentukan habis ;

Simpanan dalam buku tabungan atas nama si penyimpan giro, yang penarikannya hanya dapat dilakukan dengan menggunakan buku tabungan pemilik aslinya, atau perintah tertulis kepada pihak sekolah.

Sebagai pemberi uang tabungan, ini berarti bahwa sekolah melaksanakan operasi perkreditan secara aktif. Dalam hal ini bahwa fungsi tabungan sebagai pemberi kredit tanpa mempersalahkan apakah kredit itu berasal dari deposito atau tabungan yang diterimanya atau bersumber pada penciptaan pengambilan yang dilakukan oleh sekolah itu sendiri.

Sebagai pemberi tabungan bagi siswa-siswi melalui sumber yang berasal dari orang tua, simpanan atau tabungan siswa maupun melalui penciptaan uang sekolah.

\subsection{Definisi Siswa}

Pengertian siswa merupakan sebutan untuk anak-anak didik pada jenjang pendidikan dasar dan menengah. Siswa merupakan satusatunya subjek yang menerima apa saja yang di berikan oleh guru saat kegitan belajar mengajar berlangsung.Siswa di gambarkan sebagai sosok yang membutuhkan bantuan orang lain untuk memperoleh ilmu pengetahuan. Selain memperoleh ilmu pengetahuan siswa juga mengalami perkembangan serta pertumbuhan dari kegiatan pendidikan tersebut. Sehingga dapat dikatakan bahwa siswa merupakan salah satu anggota masyarakat yang memiliki potensi serta usaha untuk mengembangkan dirinya. Peserta didik yang umumnya merupakan individu yang memiliki potensi yang perlu di kembangkan melalui pendidikan baik fisik maupun psikis dari lingkungan keluarga maupun dari lingkungan masyarakat di manapun ia berada. Seorang peserta didik akan di ajarkan bagaimana cara bersikap yang baik serta etika yang sopan untuk berinteraksi pada masyarakat lainnya, tentu saja hal tersebut tidak dapat melupakan peran pendidikan sebagai sumber ilmu dan salah satu unsur yang terpenting dari pendidikan. Seorang pendidik harus memahami dengan betul karakter yang ada pada peserta didiknya. Pendidik juga harus mengerti bagaimana cara mengasah potensi yang ada pada peserta didiknya. Menurut pasal 1 ayat 4 UU RI no.20 Tahun 2013 tentang pendidikan nasional :

Peserta didik adalah anggota masyarakat yang berusaha mengembangkan dirinya melalui proses pendidikan pada jalur jenjang dan jenis pendidikan tertentu. Abu Achmadi, salah satu pemerhati pendidikan ia mengungkapkan bahwa peserta didik atau siswa merupakan individu yang belum bisa dikatakan dewasa. Ia memerlukan usaha, bantuan, serta bimbingan dari seseorang untuk mencapai tingkat kedewasaannya. Ia juga mengungkapkan bahwa peserta didik juga membutuhkan bimbingan untuk menjadi pribadi yang lebih baik di depan tuhan serta di depan negara sebagai warga negara yang baik. Dengan demikian siswa atau peserta didik dapat dikatakan orang 
yang mempunyai fitrah atau potensi dasar yang ada dalam dirinya berupa fisik maupun psikis yang perlu di kembangkan melalui pendidikan. UU RI No.20 tahun 2003 telah mencamtumkan bahwa peseta didik memiliki kewajiban sebagai berikut :

Menjaga norma - norma pendidikan untuk menjamin keberlangsungan proses dan keberhasilan pendidikan.

Ikut menanggung biaya pendidikan kecuali bagi yang di bebaskan dari kewajiban tersebut.

\subsection{Alat - alat Pembuatan Aplikasi (Delphi)}

Borland Delphi adalah suatu bahasa pemrograman yang memberikan fasilitas pembutan aplikasi visual. Keunggulan bahasa pemrograman ini terletak pada produktivitas, kualitas, pengembangan perangkat lunak, kecepatan kompilasi, pola desai yang menarik serta di perkuat dengan pemrograman yang terstruktur. Borland Delphi merupakan salah satu software Sistem Manajemen Database yang mempunyai kemampuan dan fasilitas yang lebih lengkap, lebih mudah memakai dan juga lebih fleksibel. Khusus untuk pemrograman database, borland delphi menyedikan fasilitas objek yang kuat dan lengkap yang memudahkan programmer dalam membuat program. Format database yang dimiliki Delphi adalah format database Paradox, dBase, MS. Access, ODBS, SyBase, Oracle dan lain-lain.

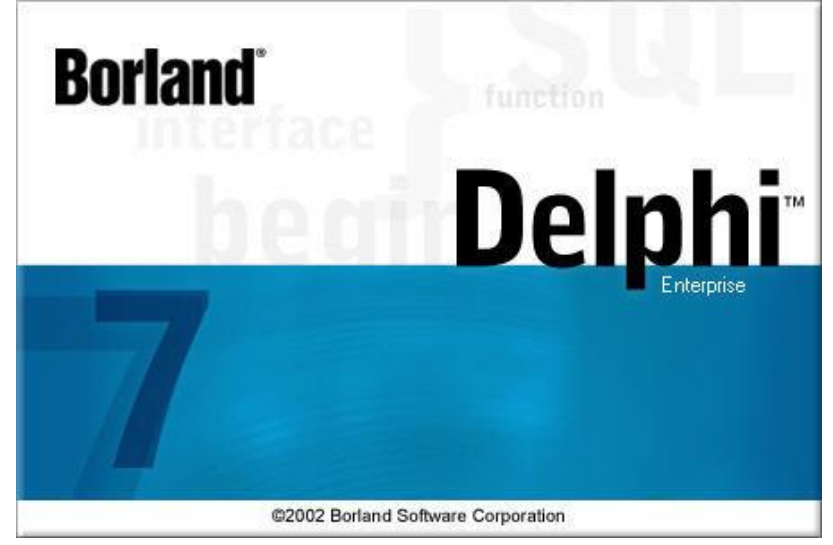

Gambar 2.2. Tampilan aplikasi borland delphi 7

(Sumber : Print screen Borland Delphi 7)

\subsection{Sejarah Borlan Delphi}

Pada tahun 1992 muncul bahasa pemrograman baru bernama Borland Pascal 7 yang merupakan penggabungan dari Turbo Pascal dan Turbo Pascal for windows. Namun ternyata bahasa pemrograman baru tersebut ternyata masih sulit digunakan. Trend penggunaan bahasa pemrograman visual untuk membangun sebuah aplikasi telah mendorong Borland membuat bahasa pemrograman baru pada tahun 1995 diperkenalkan ke pengguna komputer sebuah bahasa pemrograman visual yang berbasis bahasa pascal. Bahasa pemrograman baru tersebut diberi nama Borland Delphi setahun kemudian versi ke dua dari delphi dilempar kepasaran. Penggunaan delphi dapat mempersingkat waktu pemrograman, karena anda tidak perlu lagi menuliskan kode program yang rumit dan panjang untuk menggambar, meletakan dan mengatur komponen. Selain itu anda dapat menyusun aplikasi yang lebih interaktif. Delphi menyediakan cukup banyak pilihan komponen interface aplikasi, antara lain berupa tombol menu, drop down, ataupun menu pop up, kotak text, radio button, check box dan sebagainya. Bahkan ada berbagai macam komponen skin tampilan yang beragam yang disediakan oleh beberapa vendor lainnya, seperti, SUIoack, Sxskincomponents, dan lain sebagainya, anda tinggal memilih komponen yang dibutuhkan dengan klik mouse, mengatur tampilannya kemudian menuliskan sdikit kode program, maka aplikasi anda siap dijalankan. Delphi 7.0 versi terbaru yang dikeluarkan oleh Borland, memiliki support yang sangat tinggi terhadap database-database yang sudah terkenal (seperti Microsoft Accsses, paradox, Foxpro, Dbase, Oracee, dan lain sebagainya), dan 
dilengkapi dengan objek-objek yang baru sehingga memudahkan pembuatan database maupun program lainnya (Game, Untility, dan lainnya).

\subsection{Komponen-Komponen Borland Delphi 7}

Main Menu adalah menu yang digunakan terutama untuk memanipulasi jendela Borland Delphi. Menu Borland Delphi berisi semua perintah Borland Delphi yang dapat dipilih untuk melakukan tugas tertentu. Isi dari menu ini sebagian hampir sama dengan program-program windows pada umumnya yang dapat dilihat pada gambar 2.3.

\section{Delphi 7 - Project1 \\ File Edit Search View Project Run Component Database Tools Window}

Gambar 2.3 MenuBar pada Borland Delphi 7

(Sumber : Print screen MenuBar)

Toolbar adalah tombol-tombol yang mewakili suatu perintah tertentu dari Borland Delphi. Setiap tombol-tombol tertentu dapat langsung diklik untuk melakukan perintah tertentu yang dapat dilihat pada gambar 2.4.

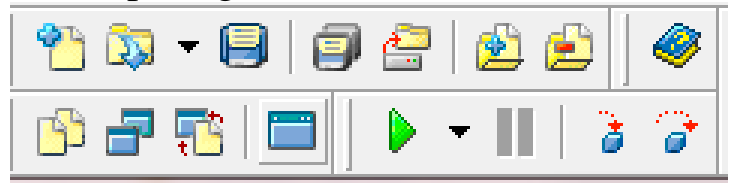

Gambar 2.4 Toolbar pada Borland Delphi 7 (Sumber : Print screen Toolbar)

Project adalah sekumpulan form, unit dan beberapa hal lain dalam program aplikasi. Singkatnya, project berguna untuk mengontrol dan mengelola beberapa tool yang akan digunakan untuk membuat aplikasi database. Dalam satu project terdapat juga beberapa file unit yang akan tersimpan dalam file berakhiran pas.

Form adalah suatu objek yang digunakan sebagai tempat kerja program aplikasi. Form berbentuk jendela dan dapat dibayangkan sebagai kertas atau meja kerja yang dapat digambari atau diletakkan objek-objek lain diatasnya yang dapat dilihat pada gambar 2.5 .

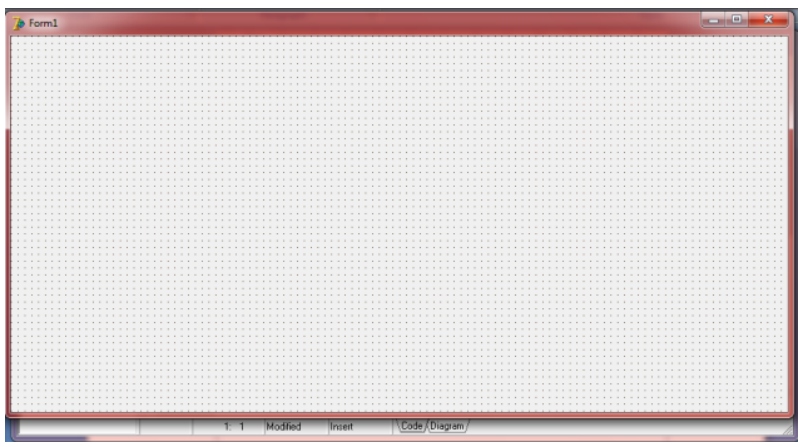

Gambar 2.5 Form Designer pada Borlnad Delphi 7

(Sumber : Print screen Designer)

Object Inspector adalah sebuah window pada Delphi yang berguna untuk mengatur tampilan event dari suatu komponen. Pada object inspector, terdapat dua tab yaitu properties dan event yaitu sebagai berikut: Tab properties digunakan untuk mengatur kelengkapan objek.

Seperti pada gambar 2.6.

\begin{tabular}{|c|c|c|}
\hline \multicolumn{2}{|l|}{ Object Inspector } & \multirow{2}{*}{$x$} \\
\hline Form1 & TForm1 & \\
\hline \multicolumn{3}{|c|}{ Properties | Events | } \\
\hline Action & & - \\
\hline ActiveControl & & \\
\hline Align & alNone & $\equiv$ \\
\hline AlphaBlend & False & \\
\hline AlphaBlendValt & 255 & \\
\hline ĐAnchors & [akLeft,akT op & \\
\hline AutoScroll & True & \\
\hline AutoSize & False & \\
\hline BiDiMade & bdLeft T oRighl & \\
\hline 田Borderlcons & [biSystemMen & \\
\hline BorderStyle & bsSizeable & \\
\hline BorderWidth & 0 & \\
\hline Caption & Form1 & \\
\hline ClientHeight & 442 & \\
\hline Clientwidth & 912 & \\
\hline Color & $\square$ clBtnFac: & - \\
\hline All shown & & $1 /$ \\
\hline
\end{tabular}

Gambar 2.6 Tab Properties Object Inspector (Sumber : Print screen Object Inspector)

Tab Events berfungsi untuk mengatur event suatu komponen. Event adalah proses eksekusi suatu kode program dikarenakan suatu aksi tertentu. Seperti pada gambar 2.7. 


\begin{tabular}{|l|}
\hline Object Inspector \\
\hline Form1 TForm1 \\
\hline Properties Events | \\
\hline Action \\
ActiveControl \\
Menu \\
ObjectMenulte \\
\hline OnActivate \\
OnCanResize \\
OnClick \\
OnClose \\
OnCloseQuery \\
OnConstrained \\
OnContextPop! \\
OnCreate \\
\hline OnDblClick \\
OnDeactivate \\
OnDestroy \\
\hline OnDockDrop \\
\hline All shown \\
\hline Oambar 2.7 Tab Event \\
\hline
\end{tabular}

Gambar 2.7 Tab Events Object Inspector (Sumber : Print screen Object Inspector)

Komponen Palette berisi kumpulan ikon yang melambangkan komponen-komponen pada VCL (Visual Component Library) seperti pada gambar 2.8.

Standard |Additional | Win32 | Sustem | DataAccess | Data Controls | dbExoress | DataSnao | BDE | ADO

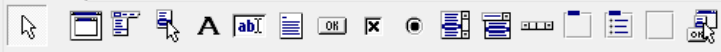

Gambar 2.8 Komponen palette (Sumber : Print screen Komponen Palette)

Adapun kegunaan tombol-tombol yang terdapat pada Component palette adalah sebagai berikut:

Tabel 2.1 Komponen-komponen Toolbar (sumber : Google)

\begin{tabular}{|l|l|}
\hline Komponen & Fungsi \\
\hline Pointer & Pointer adalah komponen \\
Khusus dan terdapat di \\
setiap tab ralam \\
component & palette. \\
& Komponen r pointer \\
adalah komponen select \\
yang digunakan untuk \\
memilih romponen- \\
komponen dalam form \\
designer. \\
\hline
\end{tabular}

\begin{tabular}{|c|c|}
\hline $\begin{array}{l}\text { Frames } \\
\square\end{array}$ & $\begin{array}{lr}\text { Frames adalah sebuah } \\
\text { kontainer } \\
\text { digunakan } \\
\text { menampung komponen. } \\
\text { Frames dapat diletakan } \\
\text { dalam form atau frame- } \\
\text { frame yang lain. }\end{array}$ \\
\hline Main menu & $\begin{array}{l}\text { Komponen yang } \\
\text { digunakan untuk } \\
\text { membuat menu bar dan } \\
\text { menu drop down. }\end{array}$ \\
\hline $\begin{array}{l}\text { РорUрМепи } \\
\text { 毁 }\end{array}$ & $\begin{array}{lr}\text { PopUpMenu } & \text { adalah } \\
\text { komponen } & \text { yang } \\
\text { digunakan } & \text { untuk } \\
\text { membuat menu Popup } \\
\text { yang akan muncul jika } \\
\text { pemakai melakukan } \\
\text { proses klik kanan }\end{array}$ \\
\hline $\begin{array}{l}\text { Label } \\
\mathbf{A}\end{array}$ & $\begin{array}{l}\text { Label adalah komponen } \\
\text { hanya digunakan untuk } \\
\text { menambahkan } \\
\text { dalam form. }\end{array}$ \\
\hline $\begin{array}{r}\text { Edit } \\
\qquad \mathbf{a b}]\end{array}$ & $\begin{array}{l}\text { Edit adalah komponen } \\
\text { yang digunakan untuk } \\
\text { menerima satu baris teks } \\
\text { yang merupakan data } \\
\text { input pemakai. } \\
\text { Komponen ini juga dapat } \\
\text { digunakan untuk } \\
\text { menampilkan teks. }\end{array}$ \\
\hline 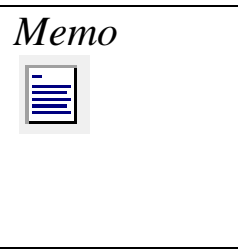 & $\begin{array}{l}\text { Memo adalah komponen } \\
\text { yang digunakan untuk } \\
\text { memasukan atau } \\
\text { menampilkan beberapa } \\
\text { baris teks di dalam form. }\end{array}$ \\
\hline $\begin{array}{c}\text { Button } \\
\text { 애 }\end{array}$ & $\begin{array}{l}\text { Button adalah komponen } \\
\text { yang digunakan untuk } \\
\text { membuat. Button yang } \\
\text { dipakai untuk membuat } \\
\text { buuton yang akan dipakai } \\
\text { untuk memilih pilihan di } \\
\text { dalam aplikasi. Jika anda } \\
\text { mengklik komponen } \\
\text { Button tersebut maka } \\
\text { suatu perintah atau } \\
\text { kejadian akan di }\end{array}$ \\
\hline
\end{tabular}




\begin{tabular}{|c|c|}
\hline & jalankan. \\
\hline $\begin{array}{l}\text { CheckBox } \\
\sqrt{\mathbf{x}}\end{array}$ & $\begin{array}{l}\text { CheckBox adalah } \\
\text { komponen yang } \\
\text { digunakan untuk memilih } \\
\text { atau membatalkan suatu } \\
\text { pilihanm yaitu dengan } \\
\text { cara mengklik } \\
\text { komponen. }\end{array}$ \\
\hline $\begin{array}{l}\text { RadioButton } \\
\text { (C) }\end{array}$ & $\begin{array}{l}\text { RadioButton } \\
\text { komponen } \\
\text { berfungsi yang } \\
\text { memberikan sekelompok } \\
\text { pilihan, dan hanya ada } \\
\text { satu pilihan yang dapat } \\
\text { dipilih untuk memilih } \\
\text { salah satu pilihan. }\end{array}$ \\
\hline $\begin{array}{l}\text { ListBox } \\
\text { 言国 }\end{array}$ & $\begin{array}{lr}\text { ListBox } & \text { adalah } \\
\text { komponen } & \text { yang } \\
\text { digunakan untuk } & \text { daftar } \\
\text { membuat sebuah } & \text { dafilan, dimana hanya } \\
\text { pilihan, } \\
\text { ada satu pilihan yang } \\
\text { dapat dipilih. Anda dapat } \\
\text { menggunakan batang } \\
\text { penggulung untuk } \\
\text { mencari dan kemudian } \\
\text { memilih salah satu } \\
\text { pilihan yang terdapat } \\
\text { dalam daftar. }\end{array}$ \\
\hline $\begin{array}{l}\text { ComboBox } \\
\text { 를 }\end{array}$ & $\begin{array}{lr}\text { ComboBox } & \text { adalah } \\
\text { komponen } & \text { yang } \\
\text { digunakan } & \text { untuk } \\
\text { membuat sebuah daftar } \\
\text { pilihan, dimana hanya } \\
\text { ada satu pilihan yang } \\
\text { dapat dipilih. Anda dapat } \\
\text { mengklik tombol drop } \\
\text { down untuk mencari dan } \\
\text { kemudian memilih salah } \\
\text { satu pilihan yang terdapat } \\
\text { di dalam daftar. }\end{array}$ \\
\hline
\end{tabular}

\begin{tabular}{|c|c|}
\hline 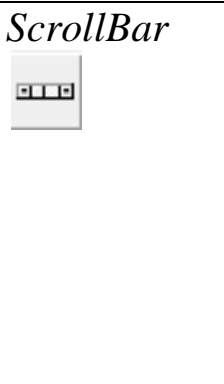 & $\begin{array}{lr}\text { ScrollBar } & \text { adalah } \\
\text { komponen } & \text { yang } \\
\text { mempunyai fungsi yang } \\
\text { sams seperti } \text { batang } \\
\text { penggulung } \\
\text { terdapat dalam program- } \\
\text { program rang } \\
\text { Windows pada umumnya. }\end{array}$ \\
\hline GroupBox & $\begin{array}{l}\text { GroupBox adalah sebuat } \\
\text { Kontainer yang dapat } \\
\text { digunakan } \\
\text { mengelompokan } \\
\text { komponen-komponen } \\
\text { lain seperti RadioButton, } \\
\text { CheckBox, } \\
\text { komponen } \\
\text { yang lain. }\end{array}$ \\
\hline $\begin{array}{l}\text { RadioGroup } \\
\text { :三 }\end{array}$ & $\begin{array}{lr}\text { RadioGroup } & \text { adalah } \\
\text { komponen } & \text { yang } \\
\text { merupakan } & \text { komponen } \\
\text { kombinasi } & \text { dari } \\
\text { GroupBox dan } & \text { didesain } \\
\text { untuk } & \text { membuat } \\
\text { sekelompok } & \\
\text { RadionButton. } & \\
\end{array}$ \\
\hline Panel & $\begin{array}{lr}\text { Panel adalah Sebuah } \\
\text { Kontainer yang dapat } \\
\text { digunakan } & \text { untuk } \\
\text { membuat status } & \text { Bar, } \\
\text { toolbar, tool palette. }\end{array}$ \\
\hline $\begin{array}{l}\text { ActionList } \\
\text { 司 }\end{array}$ & $\begin{array}{l}\text { ActionList adalah } \\
\text { komponen yang berisi } \\
\text { daftar action yang } \\
\text { digunakan bersama-sama } \\
\text { dengan komponen dan } \\
\text { Control item menu dan } \\
\text { Button. }\end{array}$ \\
\hline $\begin{array}{l}\text { Timer } \\
9\end{array}$ & $\begin{array}{l}\text { Timer adalah komponen } \\
\text { yang digunakan untuk } \\
\text { membuat object Timer }\end{array}$ \\
\hline $\begin{array}{l}\text { Datasoure } \\
\overrightarrow{\downarrow \rightarrow}\end{array}$ & 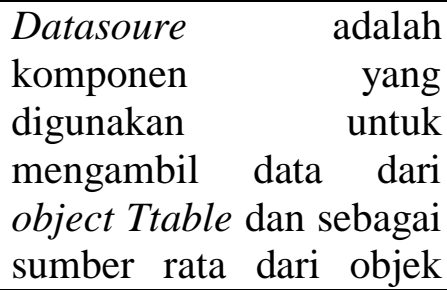 \\
\hline
\end{tabular}




\begin{tabular}{|c|c|}
\hline & lain. \\
\hline $\begin{array}{c}\text { Table } \\
\text { 佂意 }\end{array}$ & $\begin{array}{l}\text { Table adalah komponen } \\
\text { yang digunakan untuk } \\
\text { mengkaitkan table } \\
\text { database ke dalam form. }\end{array}$ \\
\hline
\end{tabular}

\section{METODE}

Metode penelitian adalah kesatuan tata cara untuk mendapatkan data yang di butuhkan untuk mendapat informasi yang di perlukan dan untuk membatu dalam penyusuna tugas akhir dan memberikan informasi kepada yang belum mengerti, pengunaan tata cara yang di gunakan oleh penulis yaitu:

\section{Studi Lapangan}

Studi lapangan adalah cara pengumpulan data dimana data tersebut di kumpulkan secara langsung untuk mempelajari dan memberikan solusi dari masalah yang dihadapi, adapun studi lapangan yang di gunkan adalah :

$\sqrt{ }$ Wawancara.

Wawancara adalah metode pengumpulan data dengan cara melakukan wawancara kepada Ibu Anita selaku bidang Administrasi dan keuangan SMP Muhammadiyah Ahmad Dahlan.

$\sqrt{ }$ Pengamatan (Observasi).

Observasi adalah metode pengumpulan data dengan cara melakukan pengamatan secara langsung di SMP Muhammadiyah Ahmad Dahlan.

$\sqrt{ }$ Dokumentasi.

Dokumentasi adalah pengumpulan data dengan mengumpulkan dokumen-dokumen untuk kelengkapan pengumpulan data.

\section{Studi Pustaka}

Studi pustaka adalah metode pengumpulan data dengan cara mengumpulkan dan memperlajari literatur dan buku-buku bacaan lain yang terkait dengan masalah yang di hadapi.

\section{PEMBAHASAN}

Dari penelitian yang dilaksanakan pada SMP Muhammadiyah Ahmad Dahlan Kota Metro ditemukan beberapa masalah yaitu a) pencatatan buku Tabungan siswa masih menggunakan buku besar sehingga sering terjadinya kesalahan dalam penulisan.

b) dalam pencarian data tabungan siswa sehingga memakan waktu dikarnakan harus mencari satu persatu data tabungan siswa.

c) belum adanya apilikasi khusus yang digunakan oleh petugas administrasi sehinga mengalami kesulitan dan keterlambatan dalam pembuatan laporan, d) pembuatan laporan tabungan siswa per hari masih dilakukan dengan Microsoft Excel, hal tersebut mengakibatkan memakan waktu dalam pembuatan laporan tabungan siswa per hari.

Oleh karena itu perlu diadakan sebuah perancangan aplikasi pengolahan data tabungan berbasis delphi pada SMP Muhammadiyah Ahmad Dahlan Kota Metro. Dengan menganalisa dan mengevaluasi sistem yang sedang berjalan, pada bab ini penulis akan memberikan usulan yang merupakan pengolahan data tabungan siswa secara komputerisasi yang diharapkan akan membantu dan mempermudah pekerjaan petugas Tabungan pada SMP Muhammadiyah Ahmad Dahlan Metro dalam penghitungan dan proses pembuatan laporan per bulan yang lebih efektif dan efisien. Sistem yang penulis ajukan disini adalah mengoptimalkan kinerja komputer, sistem yang baru diusulkan ini menggunakan bahasa pemrograman Borland Delphi 7.0, Data yang diolah merupakan data tabungan siswa/siswi SMP Muhammadiyah Ahmad Dahlan, Pengolahan cetak laporan data tabungan pada SMP Muhammadiyah Ahmad Dahlan di lakukan dalam 1 bulan sekali menggunakan Quick Report, dan Pencarian data tabungan siswa dilakukan berdasarkan Nis maupun nama siswa/siswi SMP Muhammadiyah Ahmad Dahlan, hal ini merupakan alternatif dalam pengembangan sistem kerja yang ada pada SMP 
Muhammadiyah Ahmad Dahlan. Oleh karena itu diharapkan pada sistem usulan ini dapat meningkatkan mengenai pengolahan data tabungan siswa yang lebih efektif.

\subsection{Analisis Kebutuhan Sistem}

Analisis kebutuhan sistem yang diperoleh dari berbagai literatur, proses wawancara dengan petugas Tabungan maupun sumbersumber lain dari buku berkaitan dengan program Aplikasi Pengolahan Data tabungan siswa pada SMP Muhammadiyah Ahmad Dahlan Kota Metro.

Analisis kebutuhan sistem yang dibutuhkan meliputi:

Data Masukan (Input).

Data masukan (input) yang diperlukan sebagai bahan pembuatan program tabungan siswa meliputi data siswa, data tabungan, data kelas, dan tabel entry Tabungan.

Proses (Process).

Petugas tabungan mengelola data siswa, data tabungan, data kelas, data tahun ajaran, dan data entry tabungan. Kemudian sistem akan menyimpan data tersebut kedalam database yang semuannya sudah berelasi antara tabel satu dengan tabel yang lain. Sistem ini juga bekerja untuk mengecek data tabungan, keamanan penyimpanan dan mencetak laporan.

Keluaran (output) yang dihasilkan.

Keluaran (output) yang dihasilkan oleh sistem adalah pengelolaan data tabungan siswa. Berdasarkan analisis kebutuhan sistem, diperoleh sepesifikasi sistem yang akan diimplementasikan ke dalam pengolahan data tabungan siswa, adapun sepesifikasi yang dibutuhkan meliputi:

$\sqrt{ }$ Dapat menerima input data siswa, data tabungan, data kelas, dan data entry tabungan secara berelasi antar tabel atau otomatis.

$\sqrt{ }$ Dapat mengamankan hak akses pengguna aplikasi, agar tidak semua petugas bisa mengelola data-data yang rahasia. $\sqrt{ }$ Dapat memproses laporan tabungan siswa per individu dan keseluruhan, meliputi data siswa, data tabungan, dan data kelas.

$\sqrt{ }$ Dapat mengecek data tabungan siswa secara lebih cepat dan efektif.

$\sqrt{ }$ Implementasi pada sistem yang penulis buat bagaimana dalam perancangan program tabungan siswa dapat memudahkan bagi pihak sekolah khusunya petugas tabungan dalam mengolah data tabungan siswa.

\subsection{Tujuan Dan Kegunaan Perancangan}

Tujuan Perancangan

Dalam perancangan suatu program diperlukan beberapa tahap untuk menentukan arah program tersebut. Sama seperti yang penulis lakukan dalam membuat aplikasi ini, dimulai dari pengumpulan data, analisa sistem, menentukan dan membuat alur sistem, membuat relasi sistem, membuat database sistem, merancang tampilan program sampai pada hasil pembuatan program.

\section{Kegunaan Perancangan}

Kegunaan perancangan sistem aplikasi ini adalah untuk menganalisis perancangan aplikasi pengolahan data tabungan pada SMP Muhammdiyah Ahmad Dahlan Kota Metro. Rancangan aplikasi ini yang diusulkan mampu menginputkan data, menyimpan data, mengedit, menghapus dan melakukan pencarian. Rancangan ini diusulkan sebagai masukan yang dapat dipertimbangkan untuk meningkatkan efektifitas kerja.

\subsection{Gambaran Umum Sistem Yang Diusulkan}

Aplikasi yang diusulkan memiliki beberapa keunggulan dari pengolahan data tabungan siswa pada SMP Muhammadiyah Ahmad Dahlan Kota Metro. Aplikasi yang di 
usulkan ini telah terkomputerisasi, lebih mudah digunakan dan memperhemat waktu dalam proses pengolahan data tabungan siswa, pencarian nama siswa maupun pembuatan laporan per 1 bulan.

\subsection{Rancangan Prosedur Yang Diusulkan}

Pada tahapan perancangan prosedur ini bertujuan untuk menghasilkan sebuah perancangan aplikasi pengolahan data tabungan siswa yang berbasis komputer. Adapun perancangan proses ini mencakup flowchart, diagram konteks, data flow diagram, dan erd.

Bagan Aliran Dokumen (Flowchart)

Bagan alir (flowchart) merupakan bagan (chart) yang menunjukkan alir (flow) didalam program atau prosedur sistem secara logika. Yang dapat dilihat pada tabel 4.1 dibawah ini.

Tabel 4.1 Bagan alir dokumen tabungan pada SMP Muhammadiyah Ahmad Dahlan Kota Metro.

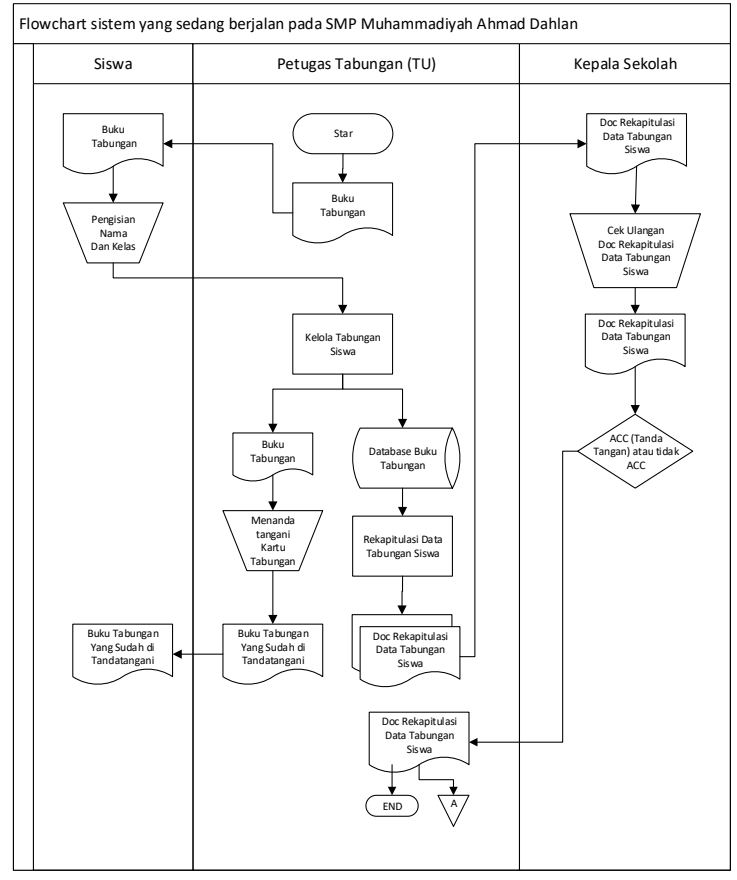

4.5 Data Flow Diagram (DFD)

a. Data Flow Diagram (DFD)
DFD berfungsi untuk para pengguna bila ingin megetahui arus data yang terjadi dalam suatu sistem pengolahan data tabungan siswa, DFD level 0 dapat dilihat pada gambar 4.2.

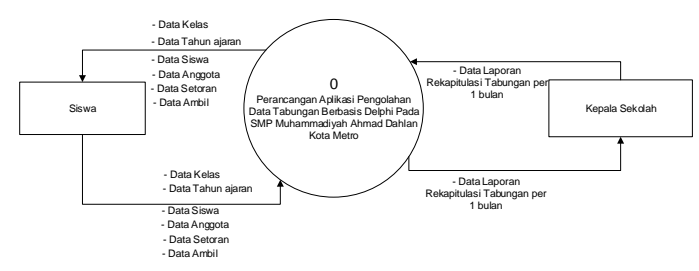

Gambar 4.2 Data Flow Diagram Level 0/ Diagram Konteks

Pada tahapan pemodelan proses ini penulis juga merancang DFD Level 1 tersebut berasal dari turunan DFD Konteks, adapun DFD Level 1 dapat dilihat pada gambar 4.2.

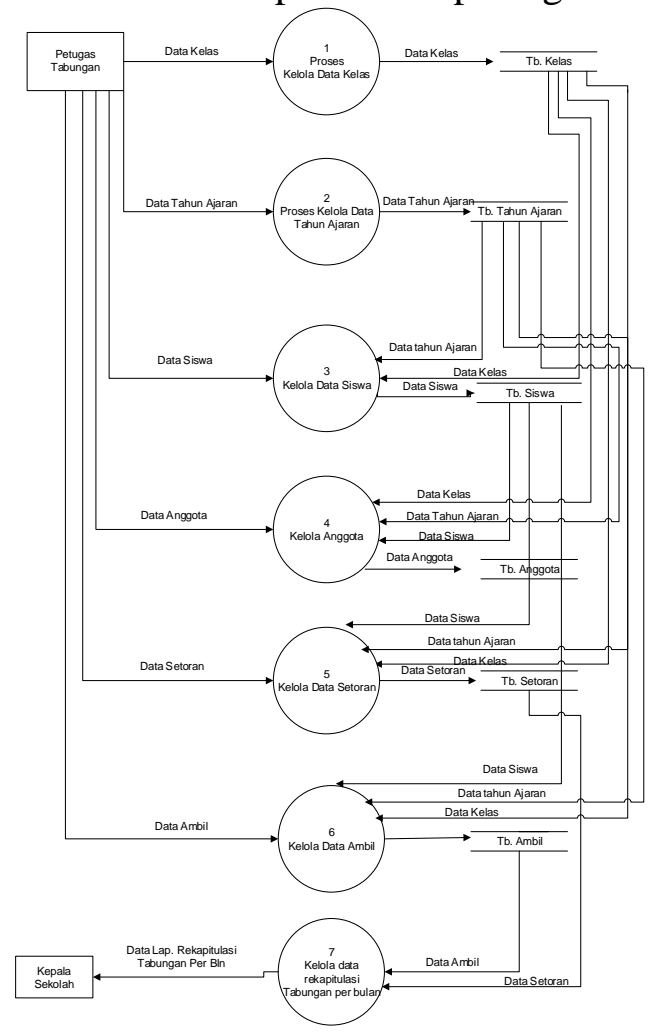

Gambar 4.2 Data Flow Diagram (DFD) Level 1

b. Entity Relationship Diagram (ERD) 
Entity Relationship Diagram (ERD) adalah suatu model jaringan yang menggunakan susunan data yang disimpan dalam sistem secara abstrak. Seperti Gambar 4.3 sebagai berikut : berikut, Id_siswa, Id_kelas, Id_tahunajaran, Nis, Nama_siswa, Kelas, Tahun_ajaran, Alamat, No_telpon, Jenis_kelamin, Agama.

Nama Tabel :t_siswa

Field Kunci : Id_siswa

Tabel 4.1 Tipe data table siswa

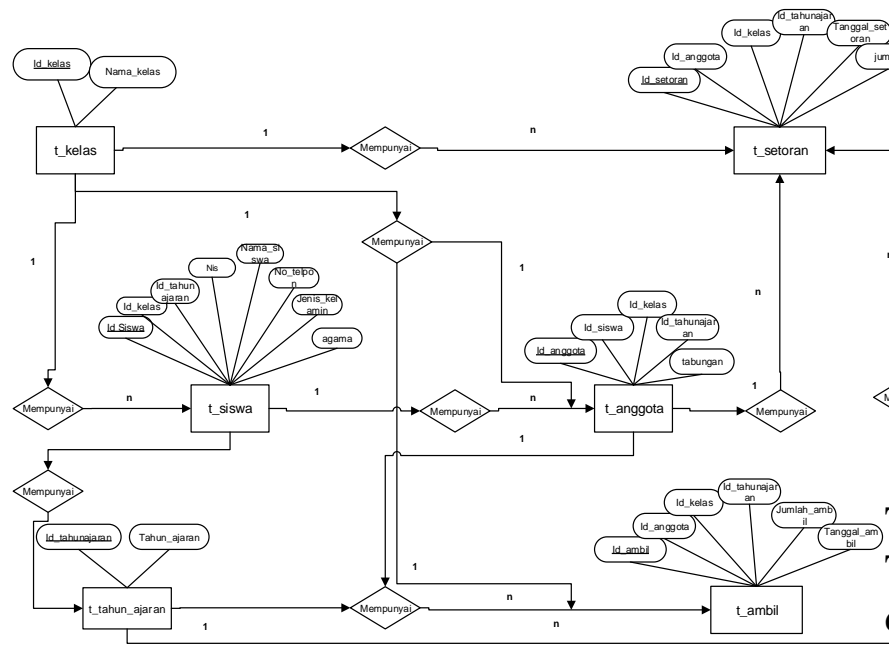

Keterangan :

$\mathrm{n}$ : Banyak

1 : Satu

Gambar 4.3 Entity Relationship Diagram (ERD)

\subsection{Rancangan File/Basis data}

Dengan basis data pengguna dapat menyimpan data secara terorganisasi setelah data disimpan, informasi dapat mudah diambil. Cara data disimpan dalam basisdata menentukan seberapa mudah mencari informasi berdasarkan banyak kriterian, datapun harus mudah ditambahkan kedalam basis data, di modifikasi, dan dihapus. Untuk menyimpan data tabungan siswa diperlukan sebuah database.

Nama Database : db_tabungan

Terdiri dari tabel : t_siswa, t_kelas, t_tahun_ajaran, t_transaksi t_tabungan, t_login.

\section{Tabel Siswa}

Tabel siswa digunakan untuk data siswa yang didalamnya terdapat field-field sebagai

\begin{tabular}{|c|c|c|c|c|}
\hline No & Nama Field & Jenis & Ukuran & Keterangan \\
\hline 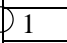 & Id_siswa & Integer & 11 & \begin{tabular}{|l} 
File Kunci \\
\end{tabular} \\
\hline 2 & Id_kelas & teger & 11 & Id kelas \\
\hline 3 & Id_tahunajaran & Integer & 11 & $\begin{array}{l}\text { Id tahunajran } \\
\text { siswa }\end{array}$ \\
\hline 4 & Nis & teger & 20 & \begin{tabular}{|l|} 
Nis siswa \\
\end{tabular} \\
\hline 5 & Nama_siswa & Varchar & 50 & Nama siswa \\
\hline 7 & Tahun_ajaran & Date & & \begin{tabular}{|l|} 
Tahun ajaran \\
\end{tabular} \\
\hline 9 & No_tel & Inte & 20 & $\begin{array}{l}\text { No telpon } \\
\text { orang tua }\end{array}$ \\
\hline 10 & Jenis_kelamin & Varchar & 10 & $\begin{array}{l}\text { Jenis kelamin } \\
\text { siswa }\end{array}$ \\
\hline 11 & Agama & Varchar & 15 & Agama siswa \\
\hline \multirow{2}{*}{\multicolumn{5}{|c|}{$\begin{array}{l}\text { Tabel Kelas } \\
\text { Tlabel kelas digunakan untuk data kelas yang } \\
\text { didalamnya terdapat field-field sebagai } \\
\text { berikut, id kelas, nama kelas. }\end{array}$}} \\
\hline & & & & \\
\hline \multicolumn{5}{|c|}{ abel 4.2 Tipe data tabel kelas } \\
\hline No & Nama Field & Jenis & Ukuran & Keterangan \\
\hline 1 & Id_kelas & Inte & 11 & Id tabel kelas \\
\hline 2 & Nama_kelas & Varchar & 30 & $\begin{array}{l}\text { Nama } \\
\text { siswa }\end{array}$ \\
\hline
\end{tabular}

Tabel Tahun Ajaran

Tabel tahun ajaran ini digunakan untuk mengisi data tahun ajaran siswa yang didalamnya terdapat filed-field sebagai berikut, id, tahun_ajaran, semester, mulai, akhir.

Nama Tabel : t_tahun_ajaran

Field_Kunci : Id_tahun_ajaran

Tabel 4.3 Tipe data tabel tahun ajaran

\begin{tabular}{|l|l|l|l|l|}
\hline No & Nama Field & Jenis & Ukuran & Keterangan \\
\hline 1 & Id_tahun_ajaran & Integer & 11 & $\begin{array}{l}\text { Tabel tahun } \\
\text { ajaran }\end{array}$ \\
\hline 2 & Tahun_ajaran & Varchar & 10 & $\begin{array}{l}\text { Tahun ajaran } \\
\text { siswa }\end{array}$ \\
\hline
\end{tabular}

Tabel Anggota

Tabel anggota digunakan untuk tabungan siswa yang didalamnya terdapat field-field 
sebagai berikut, Id_anggota, id_siswa, id_tahunajaran, id_kelas, Nama_siswa, Jenis_kelamin, Alamat, Nis, Telpon, Nama_kelas, Tahun_ajaran, Tabungan.

Nama Tabel :t_anggota

Field_Kunci : id_anggota

Tabel 4.5 Tipe data tabel anggota

\begin{tabular}{|l|l|l|l|l|}
\hline No & Nama Field & Jenis & Ukuran & Keterangan \\
\hline 1 & Id_anggota & Integer & 11 & $\begin{array}{l}\text { Id tabel } \\
\text { transaksi }\end{array}$ \\
\hline 2 & Id_siswa & Integer & 11 & Id siswa \\
\hline 3 & Id_tahunajaran & Integer & 11 & $\begin{array}{l}\text { Tahun ajaran } \\
\text { siswa }\end{array}$ \\
\hline 4 & Id_kelas & integer & 11 & Id kelas siswa \\
\hline 5 & Tabungan & Fload & & $\begin{array}{l}\text { Tabungan } \\
\text { siswa }\end{array}$ \\
\hline
\end{tabular}

\section{Tabel Setoran}

Tabel setoran ini digunakan untuk pengolahan tabungan yang didalamnya terdapat field-field sebagai berikut, id_setoran, id_siswa, id_tahunajaran, id_kelas, nama_siswa, jenis_kelamin, telpon, nama_kelas, tahun_ajaran, tanggal_setoran, jumlah, nis.

Nama Tabel :t_setoran

Field_Kunci : id_setoran

Tabel 4.5 Tipe data tabel setoran

\begin{tabular}{|l|l|l|l|l|}
\hline No & Nama Field & Jenis & Ukuran & Keterangan \\
\hline 1 & Id_setoran & Integer & 11 & $\begin{array}{l}\text { Id tabel } \\
\text { setoran }\end{array}$ \\
\hline 2 & Id_anggota & Integer & 11 & Id anggota \\
\hline 3 & Id_tahunajaran & Integer & 11 & $\begin{array}{l}\text { Tahun ajaran } \\
\text { siswa }\end{array}$ \\
\hline 4 & Id_kelas & Integer & 11 & Id kelas siswa \\
\hline 5 & Tanggal_setoran & Date & 20 & $\begin{array}{l}\text { Tanggal } \\
\text { setoran }\end{array}$ \\
\hline 6 & Jumlah & Fload & & $\begin{array}{l}\text { Jumlah } \\
\text { tabungan }\end{array}$ \\
\hline
\end{tabular}

Tabel Ambil

Tabel setoran ini digunakan untuk pengolahan tabungan yang didalamnya terdapat field-field sebagai berikut, id_ambil, id_siswa, id_tahunajaran, id_kelas, nama_siswa, telpon, Nis, nama_kelas, tahun_ajaran, jumlah_ambil, tanggal_ambil, jenis_ambil.

Nama Tabel :t_ambil
Field_Kunci : id_ambil

Tabel 4.6 Tipe data tabel ambil

\begin{tabular}{|l|l|l|l|l|}
\hline No & Nama Field & Jenis & Ukuran & Keterangan \\
\hline 1 & Id_ambil & Integer & 11 & Id tabel ambil \\
\hline 2 & Id_anggota & Integer & 11 & Id anggota \\
\hline 3 & Id_tahunajaran & Integer & 11 & $\begin{array}{l}\text { Tahun ajaran } \\
\text { siswa }\end{array}$ \\
\hline 4 & Id_kelas & Integer & 11 & Id kelas siswa \\
\hline 5 & Jumlah_ambil & Float & & Jumlah setoran \\
\hline 6 & Tanggal_ambil & Date & & Tanggal ambil \\
\hline
\end{tabular}

Tabel Login

Tabel login digunakan untuk proses pertama masuk kedalam aplikasi yang didalamnya terdapat field-field sebagai berikut, Username, Password.

Nama Tabel : t_login

Field_Kunci : Password

Tabel 4.7Tipe data tabel login

\begin{tabular}{|l|l|l|l|l|}
\hline No & Nama Field & Jenis & Ukuran & Keterangan \\
\hline 1 & Username & Varchar & 20 & Username \\
\hline 2 & Password & Varchar & 20 & Password \\
\hline
\end{tabular}

\subsection{Rancangan Relasi Tabel}

Relasi adalah tehnik desain database dengan memecahkan atribut-atribut menjadi beberapa bagian kelompok, berikut adalah gambar rancangan relasi tabel dalam pembuatan sistem informasi tabungan siswa, dijelaskan pada gambar 4.4.

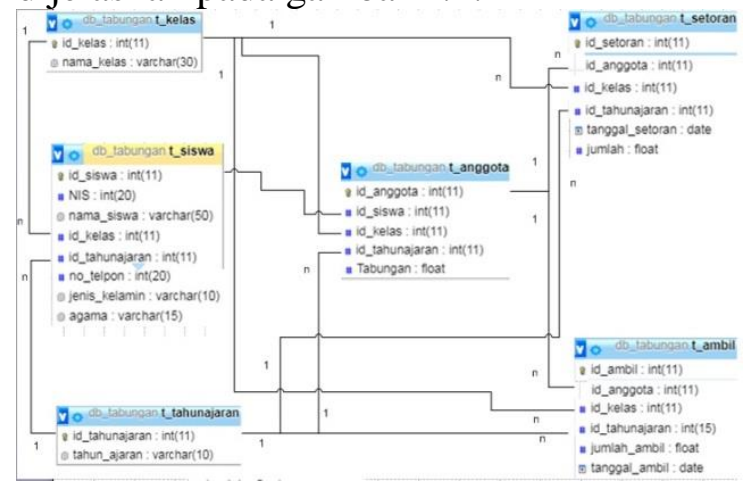

Keterangan :

* : Primary Key

** : Foreign Key

Gambar 4.4 Relasi desain database program tabungan

\subsection{Rancangan Tampilan Program}


Sesuai dengan rancangan yang penulis jabarkan dalam aliran sistem diatas maka rancangan masukan dan keluaran yang penulis rancang adalah sebagai berikut.

\subsection{Rancangan Login User}

Rancangan tampilan login user pada apikasi pengolahan data tabungan siswa, dapat dilihat pada gambar 4.5.

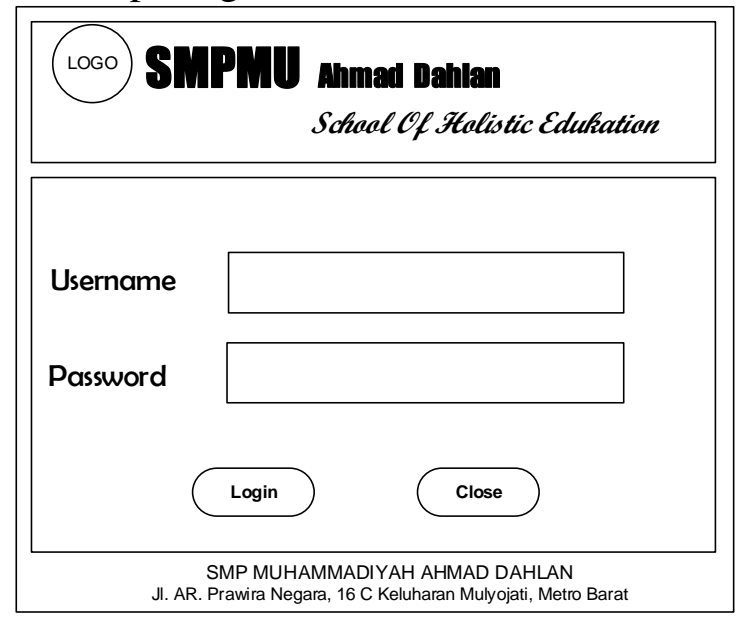

Gambar 4.5 Rancangan Login User

Rancangan pada gambar 4.6 di atas berguna untuk proses awal petugas tabungan masuk kedalam sebuah program aplikasi dan digunakan untuk pengamanan sistem tabungan, hal ini dilakukan untuk menghindari pemalsuan data karena data bersifat sangat rahasia.

\subsection{Rancangan Menu Utama}

Rancangan Menu Utama aplikasi tabungan dapat dilihat pada gambar 4.6.

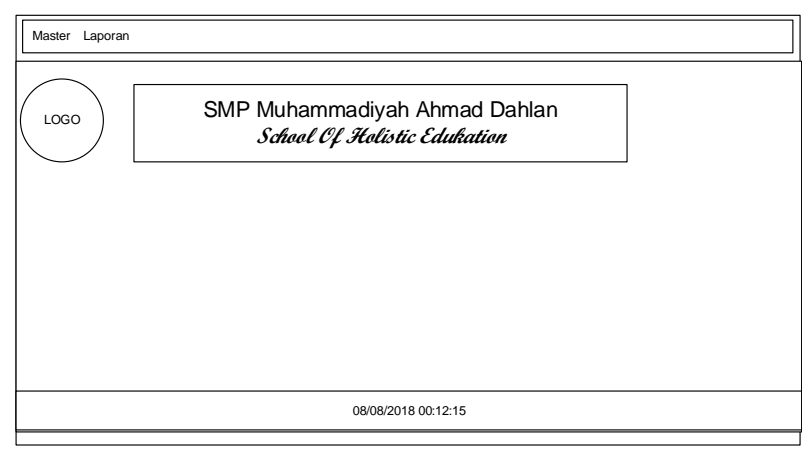

Gambar 4.6 Rancangan Menu Utama
Rancangan pada gambar 4.6 di atas yaitu menu utama yang berfungsi untuk pengguna aplikasi pengolahan data tabungan pada SMP Muhammadiyah Ahmad Dahlan Metro yang terdiri dari menu File, Master, Laporan, dan didalam tedapat, Input Siswa, Input Kelas, Input Tahun Ajaran, Input tabungan Siswa, Cetak Laporan, dan Keluar.

\subsection{Rancangan Menu Input Siswa}

Rancangan menu input siswa dapat dilihat pada gambar 4.7.

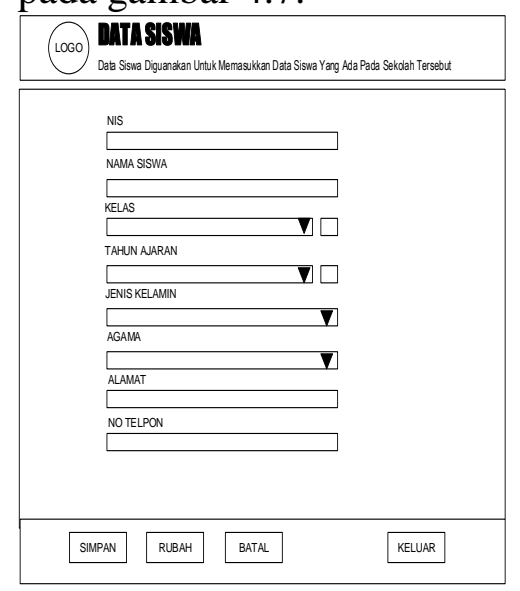

Gambar 4.7 Rancangan Input Siswa

Rancangan pada gambar 4.7 diatas adalah menu input siswa, yang di dalam nya untuk penginputan nama-nama siswa akan dirancang menggunakan program Borland Delphi 7.0.

\subsection{Rancangan Menu Input Kelas}

Rancangan menu input kelas ini digunakan untuk mengelola data kelas yang dapat dilihat pada gambar 4.8. 


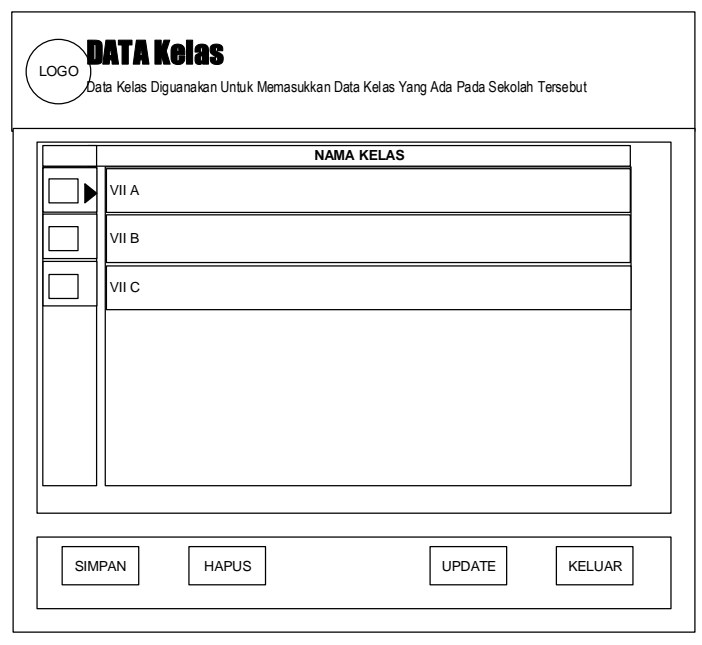

Gambar 4.8 Rancangan Input Kelas

Rancangan menu input kelas pada gambar 8 diatas ini digunakan untuk menginput data kelas pada SMP Muhammadiyah Ahmad Dahlan yang akan dirancang menggunakan program Borland Delphi 7.0.

\subsection{Rancangan Menu Tahun Ajaran}

Rancangan menu tahun ajaran ini terdiri dari input data Tahun Ajaran, Semester, Mulai, dan Akhir yang dapat dilihat pada gambar 4.9 .

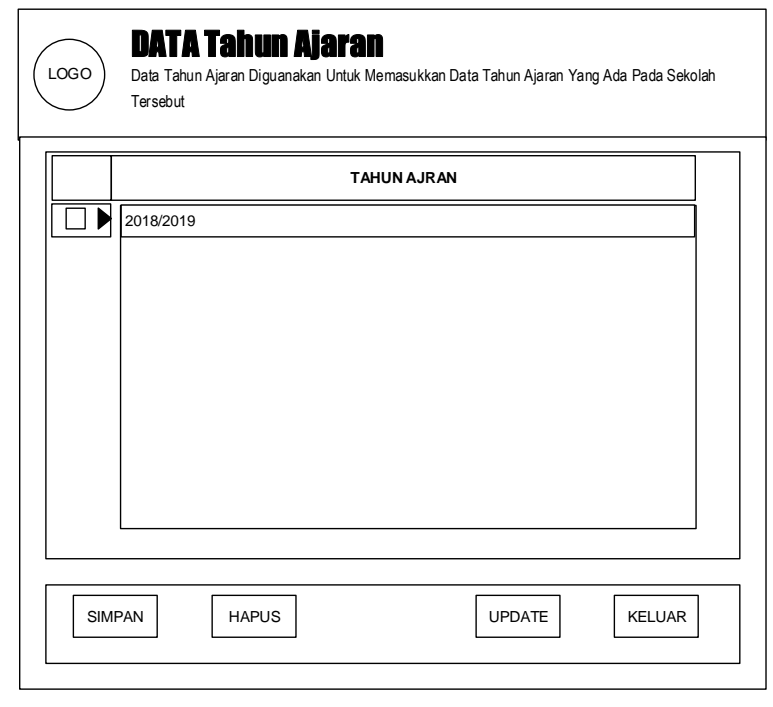

Gambar 4.9 Rancangan Menu Tahun Ajaran Rancangan menu tahun ajaran pada gambar 9 di atas adalah untuk mengelola tahun ajaran yang dibutuhkan dan akan dirancang menggunakan program Borland Delphi 7.0.

\subsection{Rancangan Entry Anggota}

Rancangan input anggota siswa yang dapat dilihat pada gambar 4.10.

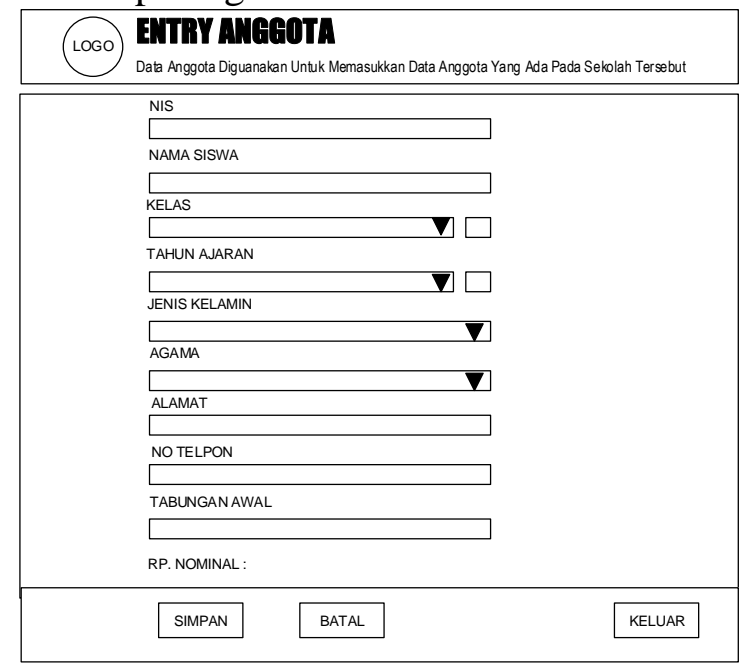

Gambar 4.10 Entry Anggota

Rancangan entry anggota pada gambar 4.10 diatas ini digunakan untuk mengelola data anggota yang sudah melakukan entry sebagai anggota.

\subsection{Rancangan Pencarian Siswa}

Rancangan pencarian nama siswa dapat dilihat pada gambar 4.11.

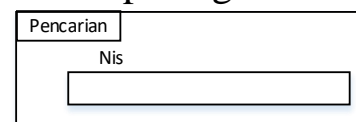

$$
\text { Nama }
$$

Gambar 4.11 Pencarian Siswa

Rancangan pencarian siswa pada gambar 4.11 diatas digunakan untuk mencari namanama siswa unutk lebih mudah.

\subsection{Rancangan Form Cetak Laporan Setoran}

Rancangan form cetak laporan perkelas, persiswa maupun per tahun ajaran dan perbulan dapat dilihat pada gambar 4.13. 


Cetak
\begin{tabular}{l} 
Dari \\
01/08/2018 \\
Sampai \\
30/08/2018 \\
Cetak Keluar \\
\hline
\end{tabular}

Cetak

Gambar 4.13 Rancangan Cetak Laporan Rancangan cetak laporan pada gambar 4.13 diatas digunakan untuk pilihan pembuatan laporan bukti uang masuk dan keluar.

\subsection{Rancangan Cetak Laporan Data Setoran}

Rancangan cetak laporan tabungan per bulan, dapat dilihat pada gambar 4.14.

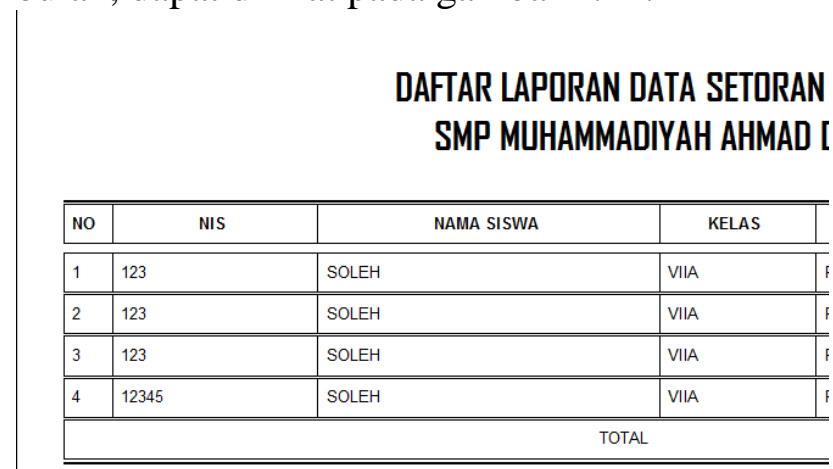

Gambar 4.14 Rancangan cetak laporan tabungan

Rancangan pada gambar 4.14 diatas merupakan hasil otput sistem tabungan yang akan di serahkan kepada Kepala Sekolah yang akan direncang menggunakan Borland Delphi 7.0.

\subsection{Rancangan Form Cetak Laporan Ambil Tabungan}

Rancangan form cetak laporan tunggakan yang dapat dilihat pada gambar 4.15.
Gambar 4.15 Rancangan Form Cetak Laporan Ambil

Rancangan form cetak laporan harian pada gambar 15 diatas digunakan untuk perintah menampilkan daftar laporan harian siswa SMP Muhammadiyah Ahmad Dahlan.

\subsection{Racanggan Cetak Laporan Ambil}

Rancangan cetak laporan id card yang dapat dilihat pada gambar 4.16.

\section{DAFTAR LAPORAN DATA PENGAMBILAN TABUNGAN} SMP MUHAMMADIYAH AHMAD DAHLAN METRD

\begin{tabular}{|l|l|l|l|l|l|}
\hline \multicolumn{1}{|c|}{ NIS } & \multicolumn{1}{c|}{ MAMA SISWA } & \multicolumn{1}{c|}{ KELAS } & \multicolumn{1}{c|}{ J. KELAMIMI } & \\
\hline \hline 1 & 123 & SOLEH & VIA & PRIA & 20 \\
\hline 2 & 12345 & SOLEH & VIA & PFIA & 20 \\
\hline 3 & 123 & SOLEH & VIA & PRIA & 20 \\
\hline \multicolumn{5}{|c|}{ TOTAL } \\
\hline \hline
\end{tabular}

Gambar 4.16 Rancangan Cetak Laporan Ambil

Rancangan cetak id card pada gambar 4.16 diatas digunakan untuk mengetahui anggota penabung.

\subsection{Implementasi dan Pembahasan Program}

Berdasarkan pembahasan yang telah dilakukan maka berikut merupakan screenshot interface program Aplikasi Pengolahan Data Tabungan siswa tentang desain yang dibuat.

Tampilan Login 
Tampilan login aplikasi Tabungan yang dapat dilihat pada gambar 4.17.

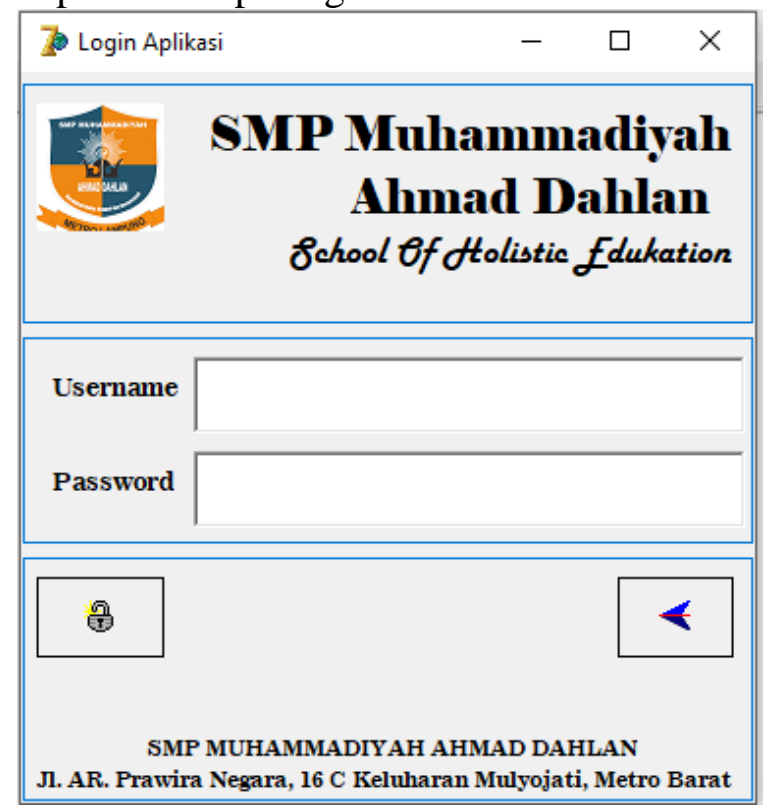

Gambar 4.17 Tampilan Login Petugas Tabungan

Tampilan Login pada gambar 4.17 diatas berfungsi sebagai tampilan login yang akan digunakan oleh petugas Tabungan untuk melakukan proses login aplikasi tabungan tersebut maka Petugas Tabungan harus mengisi kolom username dan password sehingga apa bila login berhasil maka akan diarahkan kehalaman menu utama.

\subsection{Tampilan Menu Utama}

Tampilan menu utama terdiri dari Menu Master dan Menu Laporan, berikut merupakan tampilan menu-menu tersebut :

Menu Master berisi button Data Kelas, Data Tahun Ajaran, Data Siswa, Data Anggota, Data Setoran, Ambil Tabungan seperti pada gambar 4.18.

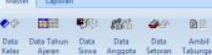

Gambar 4.18 Tampilan Menu File

\subsection{Tampilan Form Input Siswa}

Tampilan form input siswa pada aplikasi tabungan siswa yang dapat dilihat pada gambar 4.19.

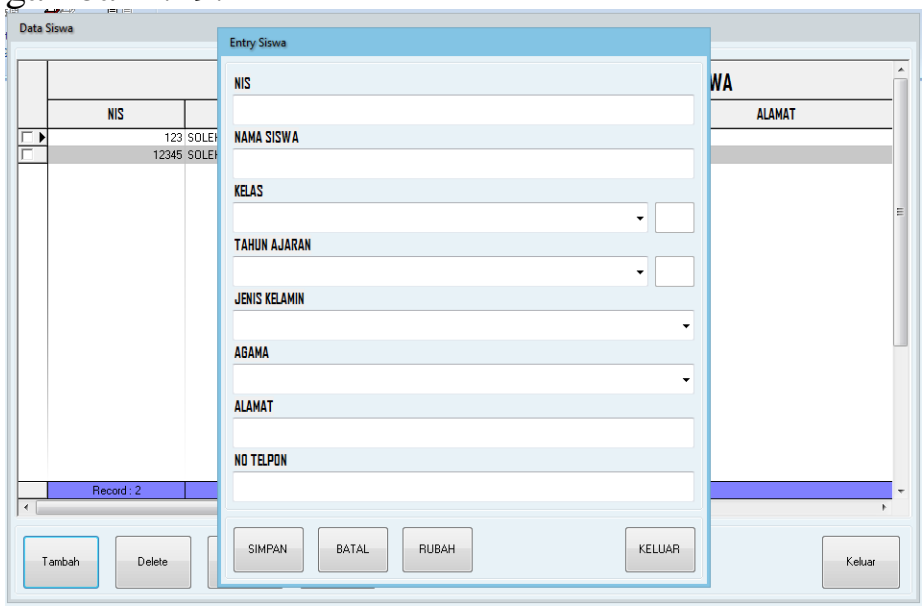

Gambar 4.19 Tampilan Form Input Siswa Tampilan menu input siswa pada gambar 4.19 diatas adalah untuk mengimput biodata siswa yang dibutuhkan untuk melengkapi proses Tabungan siswa.

\subsection{Tampilan Form Input Kelas}

Tampilan form input kelas yang dapat dilihat pada gambar 4.20. 


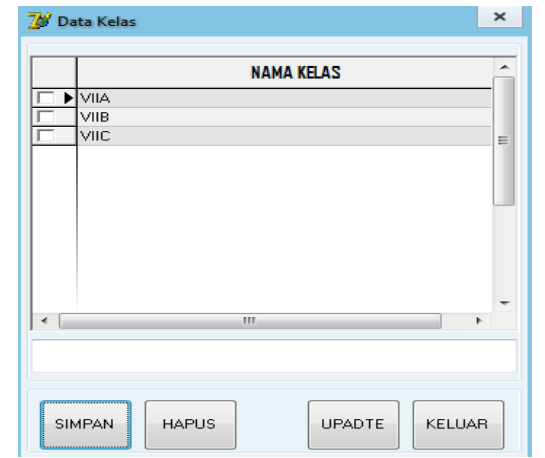

Gambar 4.20 Tampilan Form Input Kelas Tampilan Form Input kelas pada gambar 4.20 adalah digunakan untuk menginput nama kelas digunakan untuk relasi tabungan siswa SMP Muhammadiyah Ahmad Dahlan.

\subsection{Tampilan Tahun Ajaran}

Tampilan tahun ajaran dapat dilihat pada gambar 4.21.

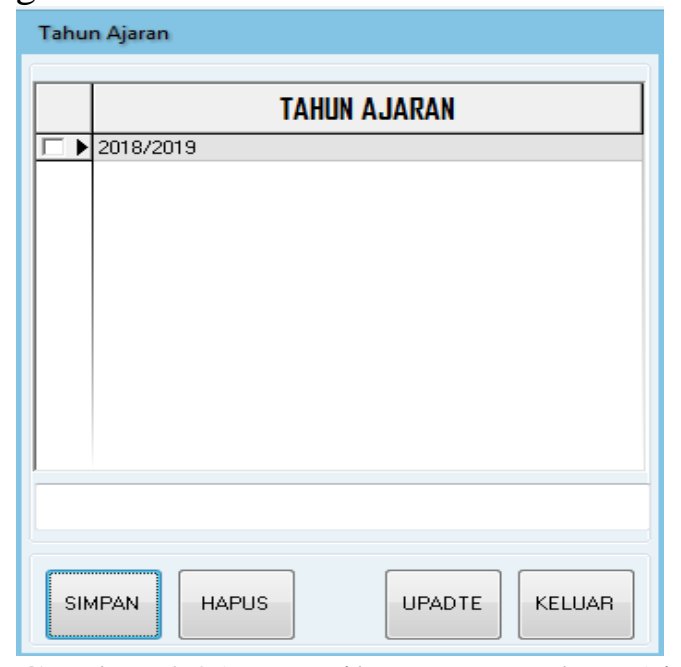

Gambar 4.21 Tampilan Form Tahun Ajaran Tampilan input tahun ajaran pada gambar 4.21 diatas digunakan untuk menginput tahun ajaran yang akan dibutuhkan oleh petugas Tabungan atau pun pihak sekolah.

\subsection{Tampilan Daftar Entry Anggota}

Tampilan Daftar Entri Anggota Tabungan pada program ini yang dapat dilihat pada gambar 4.22.

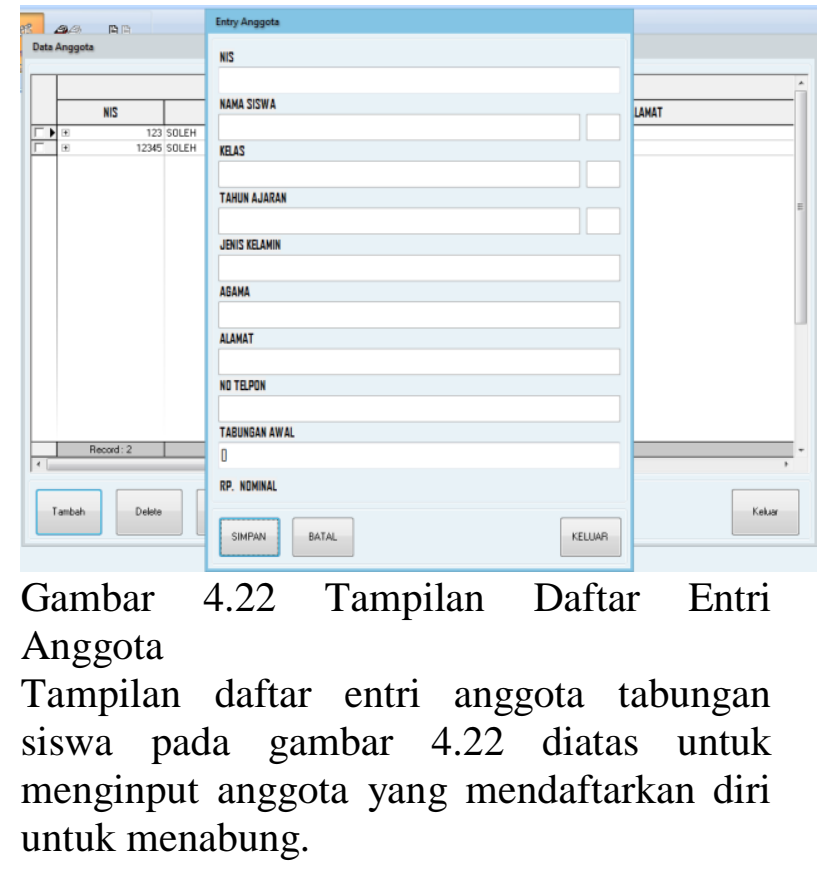

\subsection{Halaman Entri dan Daftar Transaksi Setoran Tabungan}

Tampilan input tabungan siswa yang dapat dilihat pada gambar 4.23.

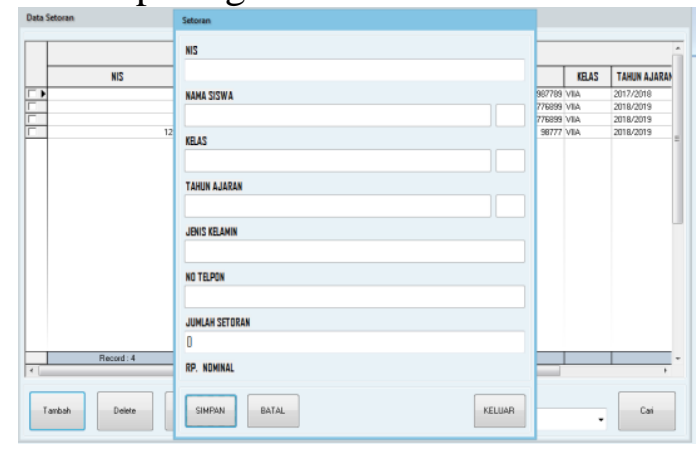

Gambar 4.23 Tampilan input Tabungan

Tampilan input tabungan siswa pada gambar 4.23 ditas adalah proses kelola tabungan siswa untuk melakukan transaksi.

\subsection{Tampilan Form Pencarian Siswa}

Tampilan menu pencarian siswa dapat dilihat pada gambar 4.24.

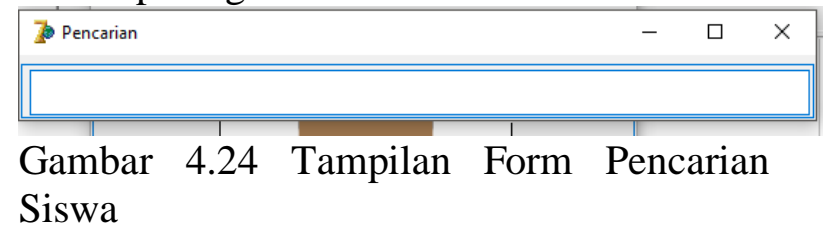


Tampilan Form pencarian siswa pada gambar 4.24 diatas ini digunakan untuk mencari nis untuk proses kelola tabungan siswa.

\subsection{Tampilan Form Cetak Laporan Setoran Tabungan}

Tampilan form cetak dapat dilihat pada gambar 4.25.

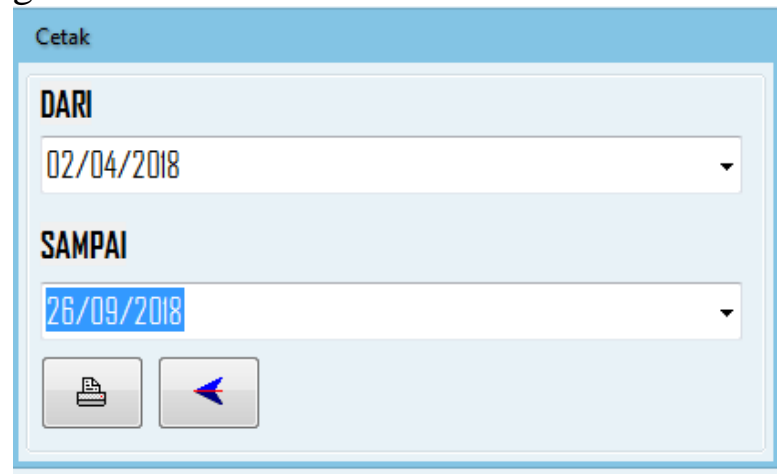

Gambar 4.25 Form Cetak

Tampilan form cetak pada gambar 4.25 diatas digunakan untuk menetukan hasil cetak laporan setoran tabungan yang di lakukan per bulan.

\subsection{Tampilan Cetak Laporan Setoran Tabungan}

Tampilan cetak laporan tabungan per bulan yang dapat dilihat pada gambar 4.26.

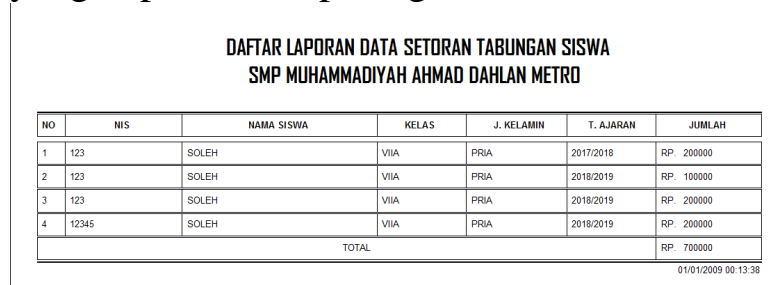

Gamabr 4.26 Tampilan cetak laporan tabungan

Tampilan cetak laporan tabungan pada gambar 4.26 diatas adalah hasil output dari tabungan siswa yang digunakan untuk dilaporkan kepada Kepala Sekolah untuk bukti data setoran tabungan siswa.

\subsection{Tampilan Form Cetak Laporan Pengambilan Tabungan}

Tampilan form cetak laporan pengambilan tabungan siswa SMP Muhammadiyah Ahmad Dahlan dapat dilihat pada gambar 4.27.

\begin{tabular}{l}
\hline Cetak \\
\hline DARI \\
\hline OI/07/2018 \\
SAMPAI \\
Gambar 4.27 Form Cetak Laporan \\
pengambilan \\
Tampilan form cetak laporan pengambilan \\
pada gambar 4.27 diatas digunakan untuk \\
perintah menentukan hasil dari cetak laporan \\
yang ingin di butuhkan.
\end{tabular}

\subsection{Tampilan Cetak Laporan Pengambilan Tabungan}

Tampilan cetak laporan pengambilan tabungan siswa dapat dilihat pada gambar 4.28 .

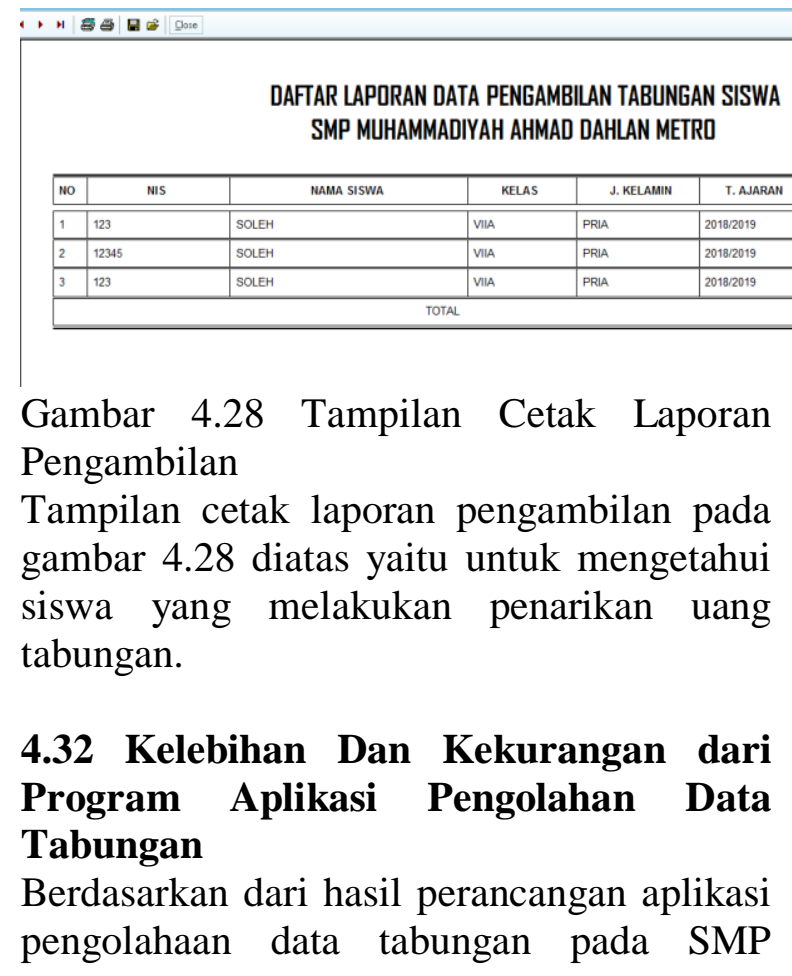


Muhammadiyah Ahmad Dahlan Metro yang penulis rancang, memiliki beberapa kelebihan dan kekurangan dalam pembuatan program ini adalah:

Kelebihan Aplikasi

Adapun kelebihan aplikasi yang dirancang oleh penulis adalah :

$\sqrt{ }$ Program yang di rancang sudah menggunakan Login User, untuk membantu keamanan pengoprasian aplikasi.

$\sqrt{ }$ Membantu dalam pengolahan dalam pembuatan laporan lebih efesien.

$\sqrt{ }$ Mempermudah petugas tabungan dalam pengolahan data Tabungan siswa.

$\sqrt{ }$ Mempermudah Petugas Tabungan dalam proses input, edit, hapus, cari maupun penyimpanan data tabungan siswa.

$\sqrt{ }$ Pencarian data siswa ataupun data penabung lebih mudah dicari.

Kekurangan Aplikasi

Adapun kekuranga atau kendala dari aplikasi pengolahan data tabungan siswa ini adalah:

$\sqrt{ }$ Program yang digunakan belum sepenuhnya bisa mengatasi masalahmasalah yang ada dalam pengolahan data tabungan siswa.

$\sqrt{ }$ Data kelas, data siswa, dan data tabungan siswa tidak dapat diakses secara online.

$\sqrt{ }$ Aksesnya masih menggunakan database MySQL dan belum berbasis server.

\section{KESIMPULAN}

Dari hasil penelitian pada SMP Muhammadiyah Ahmad Dahlan Kota Metro dapat di ambil kesimpulan sebagai berikut :

$\sqrt{ }$ Aplikasi Pengolahan Data Tabungan ini dapat mempermudah petugas Tabungan dalam pengolahan data tabungan siswa pada SMP

Muhammadiyah Ahmad Dahlan Metro.

$\sqrt{ }$ Dalam pembuatan aplikasi pengolahan data tabungan ini dapat mempermudah petugas Tabungan dalam input data siswa, pencarian data siswa, dan input data tahun ajaran siswa menjadi lebih efektif dan efesien.

$\sqrt{ }$ Program aplikasi yang penulis buat ini mempermudah petugas tabungan dalam pembuatan laporan rekap tabungan siswa lebih cepat dan terperinci.

\section{Saran}

Meskipun aplikasi ini memiliki beberapa keunggulan dalam pengolahan data tabungan siswa, namun masih memiliki banyak kekurangan di antaranya sebagai berikut :

$\sqrt{ }$ Dengan program aplikasi yang penulis buat ini diharapkan pada pihak sekolah atau petugas tabungan digunakan sehingga dapat membantu dalam pengolahan data uang tabungan siswa walaupun aplikasi ini masih sederhana.

$\sqrt{ }$ Bagi Petugas tabungan jika progam ini digunakan pada SMP Muhammadiyah Ahmad Dahlan Metro sebaiknya diadakan pelatihan supaya bisa mengoprasikan program pengolahan data tabungan ini dengan baik dan benar.

$\sqrt{ }$ Program aplikasi pengolahan data tabungan siswa ini untuk kedepannya penulis mengharapkan agar ada perubahan supaya bisa diakses secara online dan menjadi lebih baik.

\section{DAFTAR PUSTAKA}


Jurnal Mahasiswa IImu Komputer (JMIK)

Vol. 01, No. 02, Oktober 2020

[1] Adi, dwi, 2001, Kamus Bahasa

Indonesia, Fajar Mulya, Surabaya.

[7] Nugroho, Adi, 2011, Perancangan dan Implementasi Sistem Basis Data,

[2] Dahria, Muhammad, 2011, Metode Akses Data $O D B C$ dan $O L E D B$, Jurnal Saintikom.

[3] Hartono, Jogiyanto, 2005, Analisis Dan Desain, Andi Offset, Yogyakarta.

[4] Indrajani. 2014. Database Menggunakan Delphi. Jakarta: Elex Media Komputindo.

[5] Kadir, Abdul, 2003, Pengenalan Sistem Informasi, Andi Offset, Yogyakarta.

[5] Komputer, wahana, 2009, Aplikasi Cerdas Menggunakan Delphi, Andi Ofset, Yogyakarta.

[6] Ladjanudin, bin al-bahar, 2005, Analisis dan Desain Sistem Informasi, Graha Ilmu, Yogyakarta. 